\title{
Von Hippel-Lindau Syndrome-Associated Pancreatic Serous Adenoma
}

National Cancer Institute

\section{Source}

National Cancer Institute. Von Hippel-Lindau Syndrome-Associated Pancreatic Serous Adenoma. NCI Thesaurus. Code C95476.

A serous adenoma that develops in a patient with Von Hippel-Lindau syndrome. Usually there are multiple serous adenomas present of the macrocystic type. 